\title{
STUDIES ON DESOXYRIBONUCLEASE IN SYSTEMIC LUPUS ERYTHEMATOSUS. NON-PARTICIPATION OF SERUM DESOXYRIBONUCLEASE IN THE "L.E. PHENOMENON" 1
}

\section{BY NATHANIEL B. KURNICK, SANFORD PARISER,2 LAWRENCE I. SCHWARTZ, STANLEY L. LEE, AND WALLACE IRVINE \\ (From the Department of Medicine, Tulane University School of Medicine, New Orleans, La., and the Hematology and Pathology Laboratories of the Mount Sinai Hospital, New York, N. Y.)}

(Submitted for publication June 27, 1952; accepted September 12, 1952)

In 1948, Hargraves, Richmond, and Morton (1) described a new cellular element in the bone marrow of patients with acute systemic lupus erythematosus. This element, referred to as the "L.E. cell," has been confirmed by a number of investigators, and has been suggested as a diagnostic aid (2).

The L.E. cell may be formed during the incubation of normal homologous or heterologous leucocytes (3) with the sera of some patients suffering from lupus erythematosus. Haserick, Lewis, and Bortz (4) have shown that the serum factor responsible for the phenomenon resides in the gamma-globulin fraction. The L.E. cell is a polymorphonuclear neutrophilic granulocyte which contains a homogeneous, basophilic inclusion in its cytoplasm. Commonly associated with this phenomenon is the formation of rosettes (clusters of polymorphonuclear leucocytes about a large homogeneous basophilic mass) and "globs" (free homogeneous basophilic masses, approximately the size of a white blood cell). The inclusions and extracellular masses have been shown to contain desoxyribonucleic acid (DNA) in a depolymerized form (5). The hematoxylinstained bodies described in tissues of mesodermal origin by Gross (6), Ginzler and Fox (7), and Klemperer, Pollack and Baehr (8), have also been demonstrated to contain depolymerized DNA (9a, b). Since as far as is known this nucleic acid oc-

1 This work was aided by grants to Tulane University School of Medicine (N.B.K.) from the National Heart Institute, U.S.P.H.S. (No. H-714), the American Heart Association, and the Life Insurance Medical Research Fund, and to the Mount Sinai Hospital from the Life Insurance Medical Research Fund and A. A. List.

2 Anna Ruth Lowenberg Fellow in Hematology, Mount Sinai Hospital. curs, normally, exclusively as a constituent of the chromosomes, it may be concluded that the homogeneous bodies that characterize the L.E. cell phenomenon are nuclear in origin.

The DNA of normal nuclei, unlike that of the homogeneous masses characterizing the L.E. cell phenomenon, is highly polymerized (10). The participation of the specific depolymerizing enzyme, desoxyribonuclease (DNase), in the production of the L.E. cell has therefore been suggested $(9 \mathrm{~b}, 11)$. This enzyme occurs in the blood serum of many animals (12-15) and appears to be a constituent of all cells (16), including those of bacteria $(17,18)$ and yeast $(19)$. The purpose of this communication is to report investigations of the possible role of the serum $\mathrm{DNase}^{3}$ (as opposed to intracellular DNase) in the production of the L.E. phenomenon. Previous observations on human serum DNase (15) provide control data for these studies.

\section{METHODS}

A. Patients. Twenty-three patients with systemic lupus erythematosus were studied. 4 The severity of the disease process was estimated according to the presence and intensity of toxicity, fever, joint involvement, rash, anemia, cardiac and renal involvement, and rapidity of eryth-

${ }^{3}$ Preliminary studies by Dr. S. Zamenhof in collaboration with one of the authors (S. L. L.) suggested abnormal serum DNase activity in systemic lupus erythematosus.

4 We wish to acknowledge the kindness of the staff of the Roosevelt Hospital, New York City, for permitting us to study a patient in that hospital. We are indebted, also, to Dr. John Haserick of the Cleveland Clinic for providing us, in the Spring of 1950, with sera from three patients with systemic lupus erythematosus. Most of the patients were studied on the Medical Services of the Mount Sinai Hospital, New York. 
rocyte sedimentation rate. The composite clinical picture was graded arbitrarily from 0 to $4+$.

B. Estimation of serum DNase activity. Venous blood was drawn from the subjects in the fasting state, allowed to clot, and the serum separated within one hour. Merthiolate (Lilly), which has no effect on DNase activity in concentrations as high as 1:1000 (15), was added as a preservative at a concentration of $1: 100,000$. When not used immediately, the sera were stored at $-20^{\circ} \mathrm{C}$. The DNase activity of the sera was determined by the methyl green method (11), slightly modified (15).

C. Quantitation of the "L.E. cell" phenomenon. A quantitative modification of the clot technique for demonstrating the L.E. cell phenomenon (20) was performed as follows. At the same time that blood was drawn for DNase determination, $5 \mathrm{ml}$. of blood was drawn into a $15 \mathrm{ml}$. centrifuge tube and allowed to clot. The clot was agitated and removed with a wooden applicator. The tube was centrifuged and the supernatant serum decanted. The sediment was resuspended in the approximately $0.5 \mathrm{ml}$. serum which remained in the tube. The suspension was incubated at $37^{\circ} \mathrm{C}$. At intervals of 15 minutes, 30 minutes, 1 hour, 2 hours, 3 hours, 4 hours, and 24 hours, drops of the suspension were smeared on glass slides, fixed with methyl alcohol, and stained with dilute Giemsa stain. The slides were labelled with a code. To assure objectivity, all slides were examined as unknowns by a single observer who was not familiar with the code. The results were recorded as the percentage of involved cells in 500 consecutive polymorphonuclear neutrophilic granulocytes. Criteria for involvement were either the presence of the classical L.E. cell (i.e., a leucocyte with a single large cytoplasmic inclusion), or a granulocytic leucocyte containing droplet inclusions of nuclear material. Alternatively, slides were graded from 0 to 4 on the basis of the frequency of occurrence of each of the three characteristic changes: (a) L.E. cells (including those with droplet inclusions), (b) rosettes, (c) "globs." Maximal intensity of these changes was noted between the second and fourth hours of incubation and this value was recorded as a measure of the "L.E. phenomenon activity" of the serum.

The two grading systems are not directly comparable, since the percentage scheme does not provide for weighting of rosettes and "globs."

D. Leucocyte suspensions. These were prepared by a slight modification of the method of Minor and Burnett (21), by drawing blood from normal subjects into tubes containing $10 \mathrm{mg}$. heparin per $50 \mathrm{ml}$. blood. A $50 \mathrm{mg} . / \mathrm{ml}$. solution of bovine fibrinogen (Fraction I, Armour), previously dialyzed against 0.9 per cent saline to remove sodium citrate, was added $(1 \mathrm{ml}$. fibrinogen solution per 25 ml. whole blood) to hasten erythrocyte sedimentation. The blood was permitted to sediment by gravity at room temperature and within one hour the supernatant leucocyte-rich plasma was pipetted off. Leucocyte counts were performed on this plasma, and appropriate aliquots containing 5 to 10 million white blood cells were transferred to small serological test tubes, centrifuged, and the supernatant cell-free plasma decanted, leaving "cell but- tons" of known size. The cell buttons were then used as indicators for the L.E. cell phenomenon by resuspension and incubation at $37^{\circ} \mathrm{C}$. for one hour in solutions of the various serum fractions described below (E). "Buttons" were also suspended in (a) $1 \mathrm{ml} .0 .14 \mathrm{M} \mathrm{NaCl}$ containing $1 \mathrm{mg}$. crystalline bovine pancreatic DNase (22) ${ }^{5}$ and $0.003 \mathrm{M} \mathrm{MgSO}_{4}$, (b) $1 \mathrm{ml}$. containing DNase and $\mathrm{MgSO}_{4}$ as in (a) plus $2 \mathrm{mg}$. polymerized beef thymus DNA (23), and (c) $1 \mathrm{ml} .0 .14 \mathrm{M} \mathrm{NaCl}$ containing $1 \mathrm{mg}$. DNA. "Buttons" were also suspended in $1 \mathrm{ml}$. fresh serum from patients with lupus erythematosus and with $1 \mathrm{ml}$. serum previously heated to $60^{\circ} \mathrm{C}$. for 10 minutes. Aliquots of both the heated and unheated sera were tested for DNase activity.

TABLE I

Electrophoretic analysis of serum protein fractions prepared from serum of patient $W$. $G$.

\begin{tabular}{l|c|c|c|c}
\hline \hline & $\gamma$-Globulin & $\beta$-Globulin & $\alpha$-Globulin & Albumin \\
\hline Serum & $\%$ & $\%$ & $\%$ & $\%$ \\
Fraction II & 27 & 19 & 21 & 33 \\
Fraction III-A & 99 & & & \\
Fraction III & $*$ & $*$ & 54 & \\
Fraction IV-1 & & 7 & 90 & 3 \\
Fraction IV-4 & & 9 & 29 & 62 \\
Fraction V & & & & 100 \\
\hline
\end{tabular}

* Solution was too turbid for analysis, but small amount of $\boldsymbol{\gamma}$-globulin was indicated.

E. Fractionation of serum from a patient with systemic lupus erythematosus. A phlebotomy of $500 \mathrm{ml}$. was performed on patient W. G. two weeks after transfusions and cortisone therapy had been discontinued, and again one week later. After clotting, the sera were promptly separated and frozen. The $700 \mathrm{ml}$. of serum were pooled and fractionated by the Cohn Method 6 (modified) (24) and Method 9 (modified) ${ }^{\circ}$ (25). The following fractions were obtained: II, III-A, III, IV-1, IV-4, and V. Their composition is given in Table I. Aliquots were reconstituted in saline to five times their concentration in the original serum. These were tested for DNase activity in the same manner as sera. The ability of each fraction to produce the L.E. cell phenomenon was also tested, using buttons of 5 to 10 million leucocytes and $1 \mathrm{ml}$. of the serum fraction solution incubated for 1 hour at $37^{\circ} \mathrm{C}$. In the latter study, each fraction was present in a final concentration four times that of the original serum.

\section{RESULTS}

The observations on the estimation of DNase and L.E. cell provoking activities of the sera and

${ }^{5}$ Worthington Labs., Freehold, N. J.

- We are indebted to Dr. John W. Palmer and Mr. Leo Zuckerman of the Research and Development Laboratories of E. R. Squibb \& Sons, New Brunswick, New Jersey, for the preparation of these fractions and the electrophoretic analyses in Table I. 
TABLE II

Summary of clinical data, serum "L.E. phenomenon activity" and DNase activity

\begin{tabular}{|c|c|c|c|c|c|c|}
\hline \multicolumn{2}{|c|}{ Subject and date } & Age and sex & \multirow{2}{*}{$\begin{array}{c}\text { Clinical severity } \\
\begin{array}{c}+++ \\
+++\end{array}\end{array}$} & \multirow{2}{*}{$\begin{array}{l}\text { ACTH or Cortisone } \\
\text { ACTH }\end{array}$} & $\begin{array}{l}\text { Serum "L.E. } \\
\text { phenomenon } \\
\text { activity" }\end{array}$ & \multirow{2}{*}{$\begin{array}{c}\text { DNase } \times 10^{-4 \dagger} \\
\text { units/ml. } \\
124 \\
41\end{array}$} \\
\hline H. S. & $\begin{array}{l}\text { Oct. } 31,1950 \\
\text { July } 25,1951\end{array}$ & $12 \mathrm{M}$ & & & $\begin{array}{c}\text { per cent* } \\
21 \\
75\end{array}$ & \\
\hline R. B. & $\begin{array}{lr}\text { Oct. } & 10,1950 \\
\text { Jan. } & 9,1951 \\
\text { July } & 31,1951\end{array}$ & $\mathbf{M}$ & $\stackrel{+}{+}$ & $\begin{array}{l}\text { ACTH } \\
\text { ACTH } \\
\text { ACTH }\end{array}$ & $\begin{array}{l}27 \\
18 \\
64\end{array}$ & $\begin{array}{r}52 \\
0 \\
28\end{array}$ \\
\hline R. V. & $\begin{array}{lr}\text { Oct. } & 10,1950 \\
\text { Jan. } & 2,1951 \\
\text { July } & 31,1951\end{array}$ & 19 & $\begin{array}{l}+ \\
+ \\
+\end{array}$ & $\begin{array}{l}\text { ACTH } \\
\text { ACTH (1 yr.) } \\
\quad 0 \text { ( } 3 \text { mos. })\end{array}$ & $\begin{array}{r}4 \\
10 \\
54\end{array}$ & $\begin{array}{l}73 \\
67 \\
55\end{array}$ \\
\hline E. McI. & $\begin{array}{lr}\text { Aug. } & 23,1950 \\
\text { Oct. } & 17,1950 \\
\text { Jan. } & 9,1951 \\
\text { Aug. } & 2,1951\end{array}$ & 39 & $\begin{array}{c}++++ \\
+++ \\
+ \\
++\end{array}$ & $\begin{array}{c}0 \\
0 \\
\text { Cortisone } \\
0\end{array}$ & $\begin{array}{r}29 \\
5 \\
1 \\
75\end{array}$ & $\begin{array}{r}79 \\
111 \\
66 \\
157\end{array}$ \\
\hline C. & Jan. $\quad 8,1951$ & 47 & + & ACTH (6 mos.) & 1 & 71 \\
\hline 0. & Jan. $\quad 9,1951$ & $18 \quad F$ & \pm & 0 & 0 & $48 \ddagger$ \\
\hline F. W. & Nov. 14,1950 & 13 & + & ACTH & 2 & 66 \\
\hline W. G. & $\begin{array}{l}\text { July } 19,1951 \\
\text { July } 25,1951\end{array}$ & $25 \quad F$ & $\begin{array}{l}+++ \\
++\end{array}$ & $\begin{array}{l}\mathbf{0} \\
\mathbf{0}\end{array}$ & $\begin{array}{l}50 \\
60\end{array}$ & 31 \\
\hline R. K. & $\begin{array}{l}\text { July } 25,1951 \\
\text { Aug. } 20,1951\end{array}$ & 12 & $+t$ & $\begin{array}{l}\text { ACTH } \\
\text { ACTH }\end{array}$ & 25 & $\begin{array}{r}41 \\
181\end{array}$ \\
\hline E. L. & July 25,1951 & $\mathbf{M}$ & + & 0 & 26 & 41 \\
\hline C. B. & July 25,1951 & $36 \quad F$ & + & 0 & 43 & 42 \\
\hline S. K. & $\begin{array}{l}\text { July } 25,1951 \\
\text { Aug. 18, } 1951\end{array}$ & 60 & $\begin{array}{c}++ \\
++++\end{array}$ & $\begin{array}{l}\text { ACTH } \\
\text { ACTH }\end{array}$ & $\begin{array}{c}31 \\
\text { weak }\end{array}$ & $\begin{array}{l}41 \\
92\end{array}$ \\
\hline M. F. & July 25,1951 & $41 \quad F$ & ++ & ACTH & 58 & 14 \\
\hline E. $\mathrm{K}$. & July 25,1951 & F & ++ & ACTH & 3 & 21 \\
\hline F. H. & July 31,1951 & F & + & 0 & 37 & 85 \\
\hline N. M. & Aug. 2,1951 & $25 \quad F$ & $+++t$ & ACTH & 67 & 89 \\
\hline G. J. & July 31,1951 & F & +++ & 0 & 59 & 123 \\
\hline L. R. & July 31,1951 & $25 \quad M$ & ++ & 0 & 30 & 74 \\
\hline & Oct. 23,1951 & F & + & 0. & $\begin{array}{ccc}G . & L . E . & R .8 \\
0 & 2 & \frac{1}{2}\end{array}$ & 34 \\
\hline A. & Oct. 23,1951 & F & + & 0 & 2 & 44 \\
\hline L & Oct. 23,1951 & $\mathbf{F}$ & ++ & 0 & 1 & 86 \\
\hline E. B. & $\begin{array}{l}\text { Oct. } 16,1951 \\
\text { Nov. } 31,1951\end{array}$ & F & $+t$ & $\begin{array}{l}\mathbf{0} \\
\mathbf{0}\end{array}$ & $\begin{array}{l}3 \\
3\end{array}$ & $\begin{array}{l}49 \\
50\end{array}$ \\
\hline W. W. & $\begin{array}{l}\text { Jan. } 25,1951 \\
\text { Feb. } \quad 9,1951\end{array}$ & $37 \quad F$ & $\begin{array}{l}++++ \\
+++\end{array}$ & $\begin{array}{c}0 \\
\text { Cortisone }\end{array}$ & $\begin{array}{l}2 \\
3\end{array}$ & $\begin{array}{r}56 \\
338\end{array}$ \\
\hline
\end{tabular}

* Graded in per cent of polymorphonuclear neutrophilic granulocytes transformed to "L.E. cells."

+ See Kurnick (11) for definition of unit.

$¥$ Spleen (removed for treatment of thrombocytopenia) showed changes characteristic of Lupus erythematosus.

$\$$ Graded in arbitrary units 0 to 4 .

G. "Globs"

L.E. "L.E. cells"

R. Rosettes 
the clinical state of the patients are presented in Table II. The correlation coefficients $(r)$, and their probabilities of significance $(P)$ between each pair of parameters are listed in Table III.

TABLE III

Statistical analysis of correlations of data of Table II

\begin{tabular}{c|c|c}
\hline Correlations & $r$ & $P$ \\
\hline "L.E. phenomenon activity" and & & \\
serum DNase activity & .511 & .0045 \\
"L.E. phenomenon activity" and & .423 & $.0158^{*}$ \\
clinical severity & $.0162^{*}$ \\
Serum DNase activity and clinical & .362 & .012 \\
\hline
\end{tabular}

* Doubtful significance.

The L.E. phenomenon activity and serum DNase activity each reveal low order correlations of doubtful significance with the clinical severity of the disease. Although a significant correlation between serum DNase and L.E. phenomenon activity exists, it is of such a low order as to have no practical value for prediction.

The serum DNase activities of patients with systemic lupus erythematosus cover a range from 0 to $338 \times 10^{-4}$ units $/ \mathrm{ml}$. with a mean of $73 \pm$ 10 (standard error), compared to the normal range of $0-119 \times 10^{-4}$ units $/ \mathrm{ml}$. with a mean of $51 \pm 3.5$ (15). The difference between the means is probably significant $(\mathrm{P}=0.0091)$. A total of 168 determinations of the DNase activities of sera from patients with lupus erythematosus were made. Only 36 of these are included in Table II and in the calculation of the mean DNase activity, because of incomplete data on L.E. phenomenon activity or clinical state for the remaining values. If all 168 values are included, the mean serum DNase activity in acute systemic lupus erythematosus becomes $67 \pm 3.1 \times 10^{-4}$ units $/ \mathrm{ml}$, which is significantly higher than the normal mean $(\mathrm{P}=$ 0.0002 ), but not significantly different from the mean value calculated from the smaller series.

The incubation of leucocytes with bovine DNase with or without added polymerized DNA (in the absence of serum containing the L.E. factor) produced no visible alteration in the leucocyte morphology. However, if the serum with L.E. phenomenon activity was also present, the cytoplasmic inclusions of the L.E. cells were either very pale-staining or appeared as unstained vacuoles. This effect is presumably due to the dis- solution of the partially depolymerized DNA (which is responsible for the basophilia) of the inclusions by the bovine $\mathrm{DNase}$.

None of the fractions prepared from the sera of patient W. G. (see $\mathrm{E}$ above) revealed any DNase activity. Fraction II produced a strong L.E. cell phenomenon ( 86 per cent of polymorphonuclear neutrophilic leucocytes involved) while Fraction III was very slightly active (less than 1 per cent of polymorphonuclear neutrophilic granulocytes involved). None of the other fractions produced any L.E. cells.

Serum DNase was almost completely inactivated by heating for 15 minutes at $60^{\circ} \mathrm{C}$. (15). However, such heated serum produced the L.E. cell phenomenon with little or no impairment in intensity (Table IV).

TABLE IV

Effect of heating serum for 10 minutes at $60^{\circ} \mathrm{C}$ on "L.E. phenomenon activity"

\begin{tabular}{l|l|c|c|c|c}
\hline \hline Serum & Treatment & "Globs" & L.E. cells & Rosettes & Total \\
\hline R.V. & Unheated & 3 & 4 & 4 & 11 \\
R.V. & Heated & 1 & 4 & 4 & 9 \\
M.F. & Unheated & 1 & 4 & 4 & 9 \\
M.F. & Heated & 2 & 4 & 3 & 9 \\
\hline
\end{tabular}

* Intensity of reaction was scored on basis of 1 to 4 .

\section{- DISCUSSION}

The observation that bovine DNase is without effect on unfixed human leucocytes is in agreement with the observations of Ely and Ross (26) that surviving cells are not susceptible to the enzyme, whereas the DNA of dead cells is readily degraded. Presumably, viable cells are not permeable to the enzyme. The incubation of leucocytes with polymerized DNA alone, or in the presence of bovine DNase, does not induce changes resembling those of the L.E. cell. This indicates that the L.E. cell is not produced simply by the phagocytosis of DNA liberated from cells lysed in a hypothetical preliminary stage of the phenomenon.

The localization of the L.E. factor in Cohn's Fraction II (27) was confirmed. In agreement with reports (3-5) that the L.E. factor is associated with the serum gamma-globulin, Fraction II, which represents the bulk of the gamma-globulin, and Fraction III, which contains a small amount 
of gamma-globulin (Table I), were the only serum fractions found to contain L.E. phenomenon activity.

The facts that serum fractions with strong L.E. cell provoking activity were devoid of DNase activity, and that sera rendered almost free of DNase activity by heat remained potent L.E. cell producers, demonstrate that the L.E. factor and serum DNase are not directly associated. The correlation found between DNase activity of the fresh serum and its L.E. phenomenon activity, is, therefore, not a causal relationship.

Although these studies indicate that serum DNase is not responsible for the L.E. cell phenomenon, subsequent studies (28-30) suggest the participation of intracellular DNase and a DNase inhibitor in the depolymerization of DNA which characterizes this phenomenon.

\section{SUMMARY}

1. The role of serum desoxyribonuclease (DNase) in the production of the depolymerization of desoxyribonucleic acid (DNA) characteristic of the "lupus erythematosus (L.E.) cell" of Hargraves was studied. It was found that serum DNase is not responsible for the phenomenon.

2. Serum DNase activity in systemic lupus erythematosus tends to be slightly higher than normal, and displays a low order of correlation with the "L.E. phenomenon activity" of the serum. The low order correlation found between serum DNase activity and the clinical state of the patient is of doubtful significance.

3. Serum DNase is less stable to heat than the serum factor which provokes the L.E. cell transformation.

4. The L.E. cell phenomenon cannot be induced by the incubation of normal leucocytes with bovine DNase with or without added DNA.

\section{ACKNOWLEDGMENTS}

The technical assistance of Mrs. Mary Eason is gratefully acknowledged. We wish also to express our appreciation for the generous cooperation of Drs. P. Klemperer, L. Wasserman, I. Snapper and Ana Carrera in various phases of this work.

\section{REFERENCES}

1. Hargraves, M. M., Richmond, H., and Morton, R., Presentation of two bone marrow elements: the "tart" cell and the "L.E." cell. Proc. Staff Meet., Mayo Clin., 1948, 23, 25:

2. Haserick, J. R., and Sundberg, R. D., The bone marrow as a diagnostic aid in acute disseminated lupus erythematosus; report on the Hargraves' "L.E." cell. J. Invest. Dermat., 1948, 11, 209.

3. Berman, L., Axelrod, A. R., Goodman, H. L., and McClaughry, R. I., So-called "lupus erythematosus inclusion phenomenon" of bone marrow and blood: morphologic and serologic studies. Am. J. Clin. Path., 1950, 20, 403.

4. Haserick, J. R., Lewis, L. A., and Bortz, D. W., Blood factor in acute disseminated lupus erythematosus; I. Determination of gamma globulin as specific plasma fraction. Am. J. M. Sc., 1950, n.s. 219, 660 .

5. Lee, S. L., Michael, S. R., and Vural, I. L., The "L.E." (lupus erythematosus) cell: Clinical and chemical studies. Am. J. Med., 1951, 10, 446.

6. Gross, L., The heart in atypical verrucous endocarditis (Libman-Sacks) in Contributions to the Medical Sciences in honor of Emanuel Libman, New York, The International Press, 1932, vol. 2, p. 527.

7. Ginzler, A. M., and Fox, T. T., Disseminated lupus erythematosus: A cutaneous manifestation of 2 systemic disease (Libman-Sacks). Report of a case. Arch. Int. Med., 1940, 65, 26.

8. Klemperer, P., Pollack, A. D., and Baehr, G., Pathology of disseminated lupus erythematosus. Arch. Path., 1941, 32, 569.

9a. Klemperer, P., Gueft, B., and Lee, S., Nucleic acid depolymerization in systemic lupus erythematosus. J. Mt. Sinai Hosp., 1949, 16, 61.

9b. Klemperer, P., Gueft, B., Lee, S. L., Leuchtenberger, C., and Pollister, A. W., Cytological changes of systemic lupus erythematosus. Arch. Path., 1950, 49, 503.

10. Kurnick, N. B., Quantitative estimation of desoxyribosenucleic acid based on methyl green staining. Exper. Cell Res., 1950, 1, 151.

11. Kurnick, N. B., The determination of desoxyribonuclease activity by methyl green; Application to serum. Arch. Biochem., 1950, 29, 41.

12. Greenstein, J. P., and Jenrette, W. V., Physical changes in thymonucleic acid induced by protein, salts, tissue extracts, and ultraviolet irradiation. Cold Spring Harbor Symp. Quant. Biol., 1941, 9, 236.

13. McCarty, M., The inhibition of streptococcal desoxyribonuclease by rabbit and human antisera. J. Exper. Med., 1949, 90, 543.

14. Wróblewski, F., and Bodansky, O., Presence of desoxyribonuclease activity in human serum. Proc. Soc. Exper. Biol. \& Med., 1950, 74, 443.

15. Kurnick, N. B., Desoxyribonuclease activity of sera of man and some other species. Arch. Biochem. and Biophys., in press. 
16. Lang, K., Siebert, G., Baldus, I., and Corbet, A., Uber das Vorkommen von Desoxyribonuclease und Kathepsin in Zellkernen aus Nieren. Experientia, 1950, 6, 59.

17. McCarty, M., and Avery, O. T., Studies on the Chemical nature of the substance inducing transformation of pneumococcal types. III. An improved method for the isolation of the transforming substance and its application to pneumococcus types II, III, and VI. J. Exper. Med., 1946, 83, 97.

18. Tillett, W. S., Sherry, S., and Christensen, L. R., Streptococcal desoxyribonuclease: Significance in lysis of purulent exudates and production by strains of hemolytic streptococci. Proc. Soc. Exper. Biol. \& Med., 1948, 68, 184.

19. Zamenhof, S., and Chargaff, E., Studies on the desoxypentose nuclease of yeast and its specific cellular regulation. J. Biol. Chem., 1949, 180, 727.

20. Lee, S. L., A simple test for L.E. cells. Am. J. Clin. Path., 1951, 21, 492.

21. Minor, A. H., and Burnett, L., A method for obtaining living leukocytes from human peripheral blood by acceleration of erythrocyte sedimentation. Blood, 1948, 3, 799.

22. Kunitz, M., Isolation of crystalline desoxyribonuclease from beef pancreas. Science, 1948, 108, 19.

23. Mirsky, A. E., and Pollister, A. W., Chromosin, a desoxyribose nucleoprotein complex of the cell nucleus. J. Gen. Physiol., 1946, 30, 117.
24. Cohn, E. J., Strong, L. E., Hughes, W. L., Jr., Mulford, D. J., Ashworth, J. N., Melin, M., and Taylor, H. L., Preparation and properties of serum and plasma proteins. IV. A system for the separation into fractions of the protein and lipoprotein components of biological tissues and fluids. J. Am. Chem. Soc., 1946, 68, 459.

25. Oncley, J. L., Melin, M., Richert, D. A., Cameron, J. W., and Gross, P. M., Jr.; quoted by E. J. Cohn, Chapter 28, The History of Plasma Fractionation, in Advances in Military Medicine, Boston, Little, Brown and Company, 1948, page $386 \mathrm{ff}$.

26. Ely, J. O., and Ross, M. H., Lack of depolymerase effect on desoxyribonucleic acid in living cells. Science, 1949, 109, 367.

27. Pariser, S., Unpublished observations.

28. Kurnick, N. B., Discussion following paper by A. H. Sparrow, Conference on Nuclear Function, Brookhaven National Laboratory, August 15, 1951, Exper. Cell Res., in press.

29. Kurnick, N. B., Schwartz, L., Pariser, S., Lee, S., and Irvine, $W$., The role of desoxyribonuclease and a nuclease inhibitor from leucocytes in the Lupus erythematosus cell phenomenon, 44th Annual Meeting, Society for Clinical Investigation, May 5, 1952; J. Clin. Invest., 1952, 31, 645.

30. Kurnick, N. B., Schwartz, L. I., Pariser, S., and Lee, S. L., A specific inhibitor for human desoxyribonuclease from leucocytes; Its role in the lupus erythematosus cell phenomenon. To be published. 